Egyptian Journal of Aquatic Biology \& Fisheries

Zoology Department, Faculty of Science,

Ain Shams University, Cairo, Egypt.

ISSN $1110-2554$

Vol. 26(1): 159 - 180 (2022)

www.ejabf.journals.ekb.eg

\title{
A Study on the Removal Characteristics of Metal Ions from Aqueous Solution by
} Low Cost Biosorbent (Ulva lactuca)

\author{
Mohamed A. Okbah ${ }^{1 *}$, Maie I. El-Gammal', Mahmoud S. Ibrahim², \\ Khalid S. Al. El-Mabrouk ${ }^{3}$
}

1-Marine Chemistry Lab, Marine Environment Division, National Institute of Oceanography and Fisheries, NIOF, Cairo, Egypt.

2-Environmental Sciences Department, Faculty of Science, Damietta University, Egypt.

3-Ecology Department, Natural Resources and Environment Faculty, Omer Almokhtar

University, Libya.

"Corresponding author: $\underline{\text { m okbah@yahoo.com }}$

\section{ARTICLE INFO}

Article History:

Received: Nov. 24, 2021

Accepted: Dec. 28, 2021

Online:Jan. 18, 2022

Keywords:

Ulva lactuca,

Metal ions,

adsorption process,

Aqueous solution

\section{ABSTRACT}

It is important to determine the appropriate law in adsorption reactions to understand the mechanism through the process of adsorption of solute on the surface of solid materials. For this purpose, several models are recognized and fit for experimental data to explain the appropriate kinetics of the adsorption process. The mechanism of metal ions biosorption on dried Ulva lactuca was examined using a variety of analytical methods. The effect of several important factors that influence adsorption technique was determined. Different batch adsorption tests were carried out as the function of $\mathrm{pH}$, contact time, metal ion concentrations, and Ulva lactuca powder dosage. The optimum conditions for the experiments were performed at a $\mathrm{pH}$ value of 6.0 , a contact time of 90 minutes and an adsorbent dose of $0.2 \mathrm{mgL}-1$. The highest removal values for metal ions were $76 \%$ for cadmium and $79 \%$ for nickel. Kinetic experiments were also applied to estimate the adsorption equilibrium time for the metals investigated. Pseudo-first order, pseudo-second order, and the intraparticle diffusion templets were used to create three kinetic templets. For the kinetic investigations, the findings fitted well and illustrated the adsorption kinetics of $\mathrm{Cd}^{2+}$ and $\mathrm{Ni}^{2+}$ by Ulva Lactuca powder using a pseudo-second order templet with the biomass. This study confirms that Ulva Lactuca, which belongs to green algae, can be used efficiently and at a low cost to remove $\mathrm{Cd}^{2+}$ and $\mathrm{Ni}^{2+}$ from contaminated water.

\section{INTRODUCTION}

The population increase and the rapid development of various industries have led to a huge increase in the amount of wastewater generated every day. As a result, one of the most critical environmental issue is water contamination. The increase in rapid industrialization and population have increased pollutants in wastewater. Many different techniques have been used in wastewater treatment to improve its quality and reach acceptable levels. Recently, interest has increased in conducting studies related to 
biotechnology to remove trace metals from industrial effluents using inexpensive and available materials in the surrounding environment. There are several common chemical and physical , such as the sedimentation process, filtration, precipitation and adsorption, in addition to different biological methods and phytoremediation manner (Sheoran $\boldsymbol{\&}$ Sheoran, 2006), which are used to remove the polluted contaminants including trace metals. At very low concentrations, cadmium is particularly hazardous to a diversity of marine creatures. Cadmium, especially in youngsters, can harm the neurological system, kidneys and the reproductive system. Therefore, to reduce the impact of human anthropogenic trace metals inputs from agricultural practices, urban wastewater and various industries in water systems are required to protect water supplies and reduce pollution. Generally, a biological sorbent is readily available and inexpensive; these materials were challenging (Wang \& Chen, 2009). Algae is a vital sorbent material abundant in marine environments and has been used in many treatment studies. In this process, biological materials are used, whether living or dead organisms, as they can concentrate dissolved metal ions on the surface layer (Davis et al., 2003; Guibal, 2004). Several previous studies showed that many types of biomass have the ability to absorb trace metals (marine algae, fungi, bacteria and chitosan). On the other hand, researches have shown that marine algae have a high capacity to adsorb metals (Park et al., 2005; Pavasant \& Apiratikul, 2006; Vieira \& Beppu, 2006; Romera et al., 2007; Baroni et al., 2008; Mukhopadhyay, 2008; Romera et al., 2008). During the past years, there have been many studies and efforts to use non-living and readily available biomass. This biomass is capable of removing heavy metals at high rates. Microalgae have a large capacity for accumulating trace metals and hazardous chemicals, which they use to make microalgae biomass (Satpal \& Khambete, 2016). El-Sikaily et al. (2007) examined the efficiency of employing seawater dehydrated ecofriendly seaweed (Ulva lactuca) to remove hazardous Cr6+ ions from wastewater. Among the recent surveys on the usage of algae in water treatment as well as the disposal along with the removal of some toxic elements using adsorption methods, the study of Ibrahim $\boldsymbol{e t}$ al. (2016) is considered. Furthermore, Ulva lactuca was explored in the work of El-Said et al. (2018) for defluoridation from aquatic medium. Owing to their great absorption capacity and ready quantity of biomass in many coastal places throughout the world, marine algae are ranked among the most promising species in the biosorption process. One of the common methods used in these cases for treatment is the use of high biosorption methods used by many types of algae, which are inexpensive and have an effective role in removing metals (Sandau et al., 2004; Mehta \& Gaur, 2005). Thus, the use of algae in treatment processes to remove trace metals from wastewater is a significant and a promising method, especially since many types of algae are available at low cost. The high algae biosorption capacity is mainly due to the cell wall, which is mainly composed of fibers and amorphous components of polysaccharides (Sheng et al., 2004). Cadmium is able to form stable complexes with different bonds, and hence, it is one of the elements most 
easily treated from wastewater, whereas nickel complexes are less stable. Thus, nickel is one of the least removable trace metals (Ofer et al., 2003).

The present work focused on determining the extent of algae biomass (Ulva lactuca) to remove some metal ions $\left(\mathrm{Cd}^{+2}\right.$ and $\left.\mathrm{Ni}^{+2}\right)$ from an aqueous solution through the process of bio-sorption.

\section{MATERIALS AND METHODS}

\section{Chemicals}

All chemicals, including: $\mathrm{HCl}, \mathrm{HNO}_{3}$ and $\mathrm{NaOH}$ were analytical grade purchased from Aldrich Chemical Company, USA. While, $\mathrm{Cd}$ and $\mathrm{Ni}$ salts were purchased from BDH Limited, Poole, England.

The metal ion solutions used in the present study were prepared from salts of cadmium nitrate and nickel nitrate (stock, $1000 \mathrm{mg} / \mathrm{L}$ ). This was followed by preparing a series of solutions with different concentrations to be used in the experiments. The $\mathrm{pH}$ values of each mixture were adjusted to the desired values before mixing the biomass with the adsorbate, using $0.1 \mathrm{M} \mathrm{HCl}$ and $0.1 \mathrm{M} \mathrm{NaOH}$.

\section{Adsorbent (Biomass)}

Marine alga (Ulva lactuca) was collected from Abu Qir and the Eastern Harbor of Alexandria coast during spring in April 2019. All samples were manually collected from their respective locations during low tide, bathed in sea water to eliminate impurities and aerial vegetation, and afterwards transported to the laboratory in a wet condition in an ice- box. To eliminate the salt from the sample's surface, it was cleaned with tap water followed by distilled water. To remove extra water from the algae samples, blotting paper was used and dehydrated by lyophilization in a Freeze dryer (BioBlock Chaist) until constant weight was obtained (Verma et al., 2013). The dehydrated biomass was mashed with a mortar and pestle (Akar \& Tunali, 2006) and separated through a $63 \mu \mathrm{m}$ sieve to get a consistent particle size powder.

\section{Instrumental analysis}

The FTIR spectra of Ulva Lactuca powder was obtained using a Shimadzu Fourier transform infrared spectrophotometer (FTIR system-BX 0.8009) and the $\mathrm{KBr}$ disc method. The spectra were scanned in the range of 400-4000 $\mathrm{cm} 1$ under ambient circumstances using $2.0 \mathrm{mg}$ of Ulva Lactuca powder and $200.0 \mathrm{mg}$ of $\mathrm{KBr}$, with extra crushing and pallet preparation by hydraulic pallet press. A scanning electron microscope was also used to image absorbent biomass (JSM. -5300., JEOL. Ltd.). The SEM sample surface was covered with gold using an ion spray coating apparatus (JEOL. -JFC. $-1100 \mathrm{E}$.). The $\mathrm{pH}$ measurements of buffer solutions and metal ions were performed using Jenway. 3310 pH-Meter and calibrated against standard buffers of pH 4 and 9. Metal ions $\left(\mathrm{Ni}^{+2}\right.$ and $\left.\mathrm{Cd}^{+2}\right)$ concentrations were determined using inductively coupled plasma spectroscopy (ICP -OES; Model- Optima 3300 RL, Make- Perkin Elmer) at the specified 
wavelength (APHA-AWWA, 1998). All data were measured in triplicate, and data were represented as mean values in $\mu \mathrm{gg}^{-1}$ on a dry weight basis.

\section{The $\mathbf{p H}$ of point zero charge $\left(\mathbf{p H}_{\mathrm{pzc}}\right)$}

The $\mathrm{pH}_{\mathrm{pzc}}$ value of the studied biomass (Ulva Lactuca powder) was estimated according to the common method performed in previous research (Ahmad et al., 2012; Samarghandi et al., 2015; Bhaumik \& Mondal, 2016). Here, nine flasks were filled with $50.0 \mathrm{~mL}$ of $0.1 \mathrm{M} \mathrm{NaCl}$ solution. The $\mathrm{pH}$ in these nine vessels was initially adjusted to a range of 2.00 to 10.00 and the $\mathrm{pH}$ adjustment was done with $0.1 \mathrm{M}$ sodium hydroxide or hydrochloric acid solution. Then, an amount of $0.20 \mathrm{~g}$ of the dried biosorbent material was added to the nine flasks. To reach the equilibrium state, the resulting mixture was subjected to a vigorous shaking process for 24 hours at a speed of $250.0 \mathrm{rpm}$. The final $\mathrm{pH}$ value was measured and plotted against the first $\mathrm{pH}$ value, with the $\mathrm{pH}$ of the biomass. The pHpzc was determined at the point where the two curves overlap.

\section{Batch adsorption experiments}

Batch adsorption methods were performed using the weight of the biosorbent in separate conical flasks $(250 \mathrm{ml})$ containing the concentration $\left(10\right.$ and $\left.50 \mathrm{mgL}^{-1}\right)$ of metal ions $\left(\mathrm{Cd}^{2+}\right.$ and $\left.\mathrm{Ni}^{2+}\right)$, respectively. The flasks were placed in a vibrating water bath at room temperature $\left(25 \pm 0.1^{\circ} \mathrm{C}\right)$. After the biosorption process, the biosorbent was separated by centrifugation; the supernatant liquids were analyzed, and the residual metal ions concentration was measured.

\section{Influence of pH-values, metal ion concentration and stirring time}

To explore the effect of the $\mathrm{pH}$, the parameters of preliminary metal concentration, the dose of Ulva L. powder and the shaking time were fixed at $10 \mathrm{mgL}^{-1}$ for $\mathrm{Cd}^{+2}$ and 50 $\mathrm{mgL}^{-1}$ for $\mathrm{Ni}^{+2}, 0.20 \mathrm{~g}$ and $90 \mathrm{~min}$, respectively. The tested $\mathrm{Ph}$ - values ranged from 3 to 8 . $\mathrm{pH}$ was adjusted with 0.10 mole hydrochloric acid and 0.10 mole sodium hydroxide. To evaluate the influence of the concentration of the studied metals $\left(\mathrm{Cd}^{2+}\right.$ and $\mathrm{Ni}^{2+}$ ions $)$ on the biosorption process, a number of different metal concentrations of $5,10,20 \mathrm{mgL}^{-1}$ for $\mathrm{Cd}^{+2}$ and 20, 50, $100 \mathrm{mgL}^{-1}$ for $\mathrm{Ni}^{+2}$ was studied at $\mathrm{pH}$-value $=6$, with $0.2 \mathrm{gL}^{-1}$ Ulva L. powder for 90 minutes. An amount of $250 \mathrm{ml}$ of aqueous solutions of metal ions was added in previously prepared concentrations. By a magnetic stirrer, the solution was mixed for 90 minutes at $250 \mathrm{rpm}$, and $1 \mathrm{ml}$ of reaction solution was diluted to $10 \mathrm{ml}$ using DDW at intervals of $0,5,10,20,30,40,50,60,70$ and 90 minutes. This was followed by measuring the amount of the remaining metal ions. The influence of contact time was determined by stirring $0.20 \mathrm{~g}$ of Ulva L. powder with a metal solution 10 and $50 \mathrm{mgL}^{-1}$ for $\mathrm{Cd}^{2+}$ and $\mathrm{Ni}^{2+}$, respectively, at different times $(0,10,20,30,40,50,60,70,90$ minutes).

\section{Influence of adsorbent dosage and temperature change.}

To examine the impact of biomass weight regarding the adsorption procedure, different biomass weights (Ulva Lactuca powder as biosorbent) were used $(0.1,0.2,0.5$ and $1.0 \mathrm{~g}$ ) and agitated with 10 and $50 \mathrm{mgL}-1$ solutions for $\mathrm{Cd}^{2+}$ and $\mathrm{Ni}^{2+}$ ions, 
respectively, at $\mathrm{pH} 6$ for 90 minutes. Weights of biosorbent were added to $250 \mathrm{ml}$ of metal ions solution and stirred for 90 minutes, followed by standing for 3 hours. To explore the effect of heat variation on the adsorption capacity and the removal percent of $\mathrm{Cd}^{2+}$ and $\mathrm{Ni}^{2+}$ ions, the experiment was carried out at $\mathrm{T}=20,25,30,35$ and $40^{\circ} \mathrm{C}$, using an adsorbent quantity of $0.2 \mathrm{~g}$, an amount of $250 \mathrm{ml}$ containing a solution of 10 and 50 $\mathrm{mgL}^{-1}$ for $\mathrm{Cd}^{+2}$ and $\mathrm{Ni}^{+2}$ ions, respectively, at $\mathrm{pH} 6$ for 90 minutes. After any specified time, the sorbents were split up from the mixture being filtered throughout the filtering paper. The supernatant was obtained during the different stages of the study by centrifugal separation, and the remaining metals $\left(\mathrm{Cd}^{2+}\right.$ and $\left.\mathrm{Ni}^{2+}\right)$ ions were measured using ICP-OES.

\section{Removal and adsorption capacity calculation}

For the study of kinetic experiments, optimal values for the studied parameters were used; the $\mathrm{pH}$-value considered was 6.0, whereas the amount of biomass was $0.2 \mathrm{gL}^{-1}$ for solutions of different metal concentrations. All flasks were mixed at $250 \mathrm{rpm}$ at room temperature. Residual metal ions were measured at periodic intervals with initial and final concentrations. According to Li et al. (2019), the removal ratio (R\%) and equilibrium adsorption capacity $\left(\mathrm{q}_{\mathrm{e}}\right)$ of the metal ions in the solutions were described as follows:

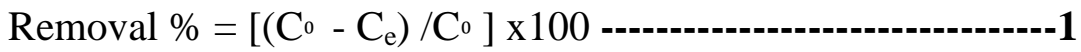

The quantity of metal ions adsorbed at equilibrium, $\mathrm{q}_{\mathrm{e}}\left(\mathrm{mg} \mathrm{g}^{-1}\right)$ was computed from the following equation:

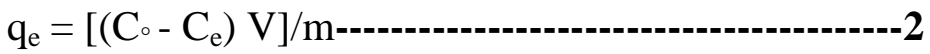

where, $\mathrm{V}$ : the mixture volume $(\mathrm{L}), \mathrm{C}^{0}$ : initial metal ions $\left(\mathrm{Cd}^{+2}\right.$ and $\left.\mathrm{Ni}^{+2}\right)$ concentration, $\mathrm{C}_{\mathrm{e}}$ : the equilibrium metal ions $\left(\mathrm{Cd}^{+2}\right.$ and $\left.\mathrm{Ni}^{+2}\right)$ concentrations in $\left(\mathrm{mgL}^{-1}\right)$, and $\mathrm{m}$ : the mass of adsorbent $(\mathrm{g})$. All of the adsorption experiments were done three times in a row, with all of the findings being measured three times in a row.

\section{RESULTS}

Chemical composition of dry biomass (Ulva Lactuca powder):

The biosorption capability of Ulva. L powder is mainly related to the structure of the cell wall, which is composed of carbohydrates, polysaccharides, lipids, proteins and other biopolymers (Sheng et al. 2004). The chemical composition of algae powder (Ulva. L) showed a relatively high amount of fiber $(51.0 \%)$, proteins $(6.9 \%)$ and lipids $(3.8 \%)$. It was also found that the fibers contained hemicellulose $(22.1 \%)$, cellulose $(8.6 \%)$ and lignin $(2.1 \%)$. The results of the protein analysis presented that the basic amino acids were about $46.0 \%$ of the total amino acids. Palmitic acid and oleic acid accounted for $58.3 .0 \%$ and $14.98 \%$ of the total fatty acids. The metal concentrations (in $\mu \mathrm{g} g-1$ dry wet.) in Ulva. L were as follows: $\mathrm{Zn}(92.5)>\mathrm{Fe}(75.0)>\mathrm{Ni}(32.5)>\mathrm{Cu}(6.8)>\mathrm{Se}(2.6)$ $>\mathrm{Pb}(0.25)>\mathrm{Cd}(0.13)$ 


\section{Adsorbent characterization}

\section{The $\mathrm{pH}$ of point zero charge (pHpzc)}

The pHZPC value of the biosorbent surface must be determined, which is a very important characteristic and defined as the $\mathrm{pH}$ at which the biosorbent surface is electrically neutral. It was found that the pHZPC value of the studied biosorbent was $<7.0$ (Fig.1). This indicates that the surface biomass of Ulva Lactuca powder is negatively charged at $\mathrm{pH}$ values up to 7 and at $\mathrm{pH}$ values $<7.0$, the surface is positively charged. Fig. (1) shows that the removal of metal ions by surface biomass is associated with pHZPC value $(\mathrm{pHZPC}=6)$. Increasing the $\mathrm{pH}$ above the $\mathrm{pHZPC}$ would give a low absorption capacity.

\section{Scanning electron microscopy (SEM)}

The SEM analysis of Ulva Lactuca powder revealed important information on surface morphology. This technique is used to show the small surfaces of the porous raw material, and it is done before and after the treatment process. The SEM of Ulva Lactuca powder showed breaking down of the cell wall; this decreased the firmness of the thalli which became brittle (Fig.2). It was evident from the micrographs that the biomass exhibits an even and relatively compact structure, interspersed with identical large channels in the adsorbed metal ions $\left(\mathrm{Cd}^{2+}\right.$ and $\left.\mathrm{Ni}^{2+}\right)$. Furthermore, the channels in the state of biomass adsorbed metal ions were larger than those before the adsorption process. These changes may have occurred when samples were exposed to a solution of metals. This occurs as a result of the process of replacing cations in solutions with some cations in the cell wall of dead algae and results in stronger crosslinking. This can be explained by the ion exchange mechanism whereby metal ions occupy available sites on the surfaces of the adsorbent material (Saravanan et al., 2011).

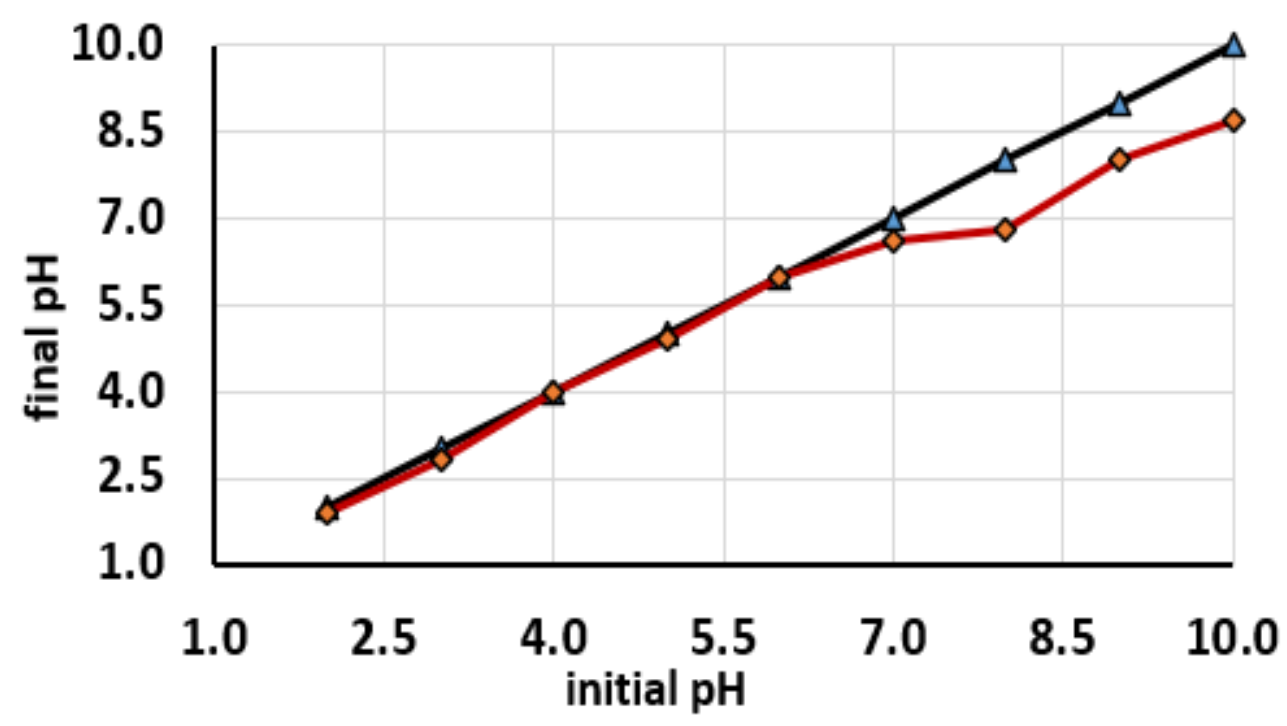

Fig.1: The point of zero charge, pHz of dried Ulva $L$ powder. 


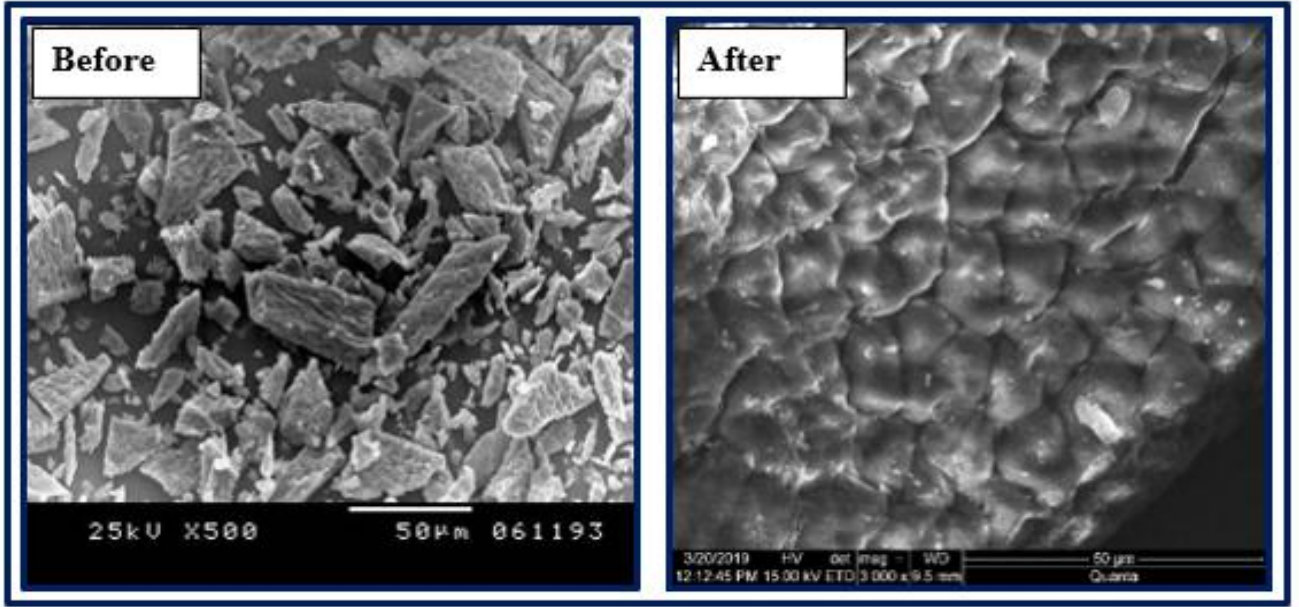

Fig. 2: Scan Electron Microscope micrograph of Ulva lactuca before and after the adsorption processes

\section{FTIR spectroscopy analysis}

The current results show that the chemical composition of the dried algae powder (Ulva Lactuca) is characterized with high content of fibres (54.0\%), minerals (19.6\%), proteins $(8.5 \%)$ and lipids $(7.9 \%)$. In addition, the neutral fibres consisted of hemicellulose $(20.6 \%)$, cellulose $(9.0 \%)$ and lignin $(1.7 \%)$. These findings are in line with those of Yaich et al. (2011).

The Fourier transform infrared (FTIR) is a useful analytical tool for discovering functional groups and analysing covalent bonding information. FTIR analysis was used in this study to identify the different functional groups present in Ulva Lactuca powder that were responsible for the adsorption process (Vieira \& Volesky, 2000).

The FTIR spectra of Ulva Lactuca powder before the adsorption process of metal ions $\left(\mathrm{Cd}^{2+}\right.$ and $\left.\mathrm{Ni}^{2+}\right)$ is presented in Fig. (3a, b). A medium broad absorption band observed at $3946 \mathrm{~cm}-1$ confirmed intra-molecular H-bonded (-OH groups). The existence of a signal at $2929 \mathrm{~cm}-1$ corroborated the asymmetric and symmetric stretching the vibrations of aliphatic $\mathrm{C}-\mathrm{H}$ stretch alkanes in the $\mathrm{CH}_{2}$ and $\mathrm{CH}_{3}$ groups. The characteristic features of FTIR spectra are the presence of absorption bands described by location, shape and intensity. The main areas of FTIR spectra interpretation are the following wavenumbers with their ranges: 4000-2500 cm-1 - vibrations of stretching bonds O-H, N-H, C-H, S$\mathrm{H} ; 2500-2000 \mathrm{~cm}-1-\mathrm{C}=\mathrm{C}=\mathrm{C}$ and triple bonds $\mathrm{C} \equiv \mathrm{N}$ and $\mathrm{C} \equiv \mathrm{C} ; 2000-1500 \mathrm{~cm}-1$ double $\mathrm{C}=\mathrm{C}, \mathrm{C}=\mathrm{O}, \mathrm{C}=\mathrm{N}, \mathrm{N}=\mathrm{N}$, deformation vibrations of bonds $\mathrm{N}-\mathrm{H}$ and $\mathrm{O}-\mathrm{H}$ from water; $1500-650 \mathrm{~cm}-1$ - fingerprint area, difficult for interpretation, valence vibrations of bonds C-C, C-N, C-O, deformation vibrations of C-H. Absorption bands of C-OH groups of phenols and alcohols (coming from stretching vibrations) are placed in 
wavenumber range of 3000-3600 cm-1 (Sakellariadou 2006). Increase of band at 23300 cm-1 can be caused by the combining of metal ions or by raised hydrogen bonding. The spectra of FTIR found before and after adsorption of metal ions $\left(\mathrm{Cd}^{2+}\right.$ and $\left.\mathrm{Ni}^{2+}\right)$ in dried Ulva L powder are observed in Fig.3 (a \& b). A broad band at $3446.9 \mathrm{~cm}-1$ before metal adsorption was slightly shifted to the peak at $3445.9 \mathrm{~cm}-1$ after adsorption, which is due to the $\mathrm{O}-\mathrm{H}$ stretching frequency, hydrogen bonding hydroxyl groups occurs (Ertani, 2011). The IR spectra at 2928.0 and $2929.9 \mathrm{~cm}^{-1}$ refer to asymmetric and symmetric $\mathrm{C}-$ $\mathrm{H}$ stretching or of $\mathrm{CH}_{2}$ groups. Generally, alkanes and cycloalkanes absorb in the range of 2850 - $3000 \mathrm{~cm}-1$. Yao et al. (2008) reported that, these bands are strong and broad, and their situation ought not alter by more than $\pm 10 \mathrm{~cm}-1$. These bands were presented at 2920 and $2860 \mathrm{~cm}-1$ (Sakellariadou, 2006). The band at $2362.9 \mathrm{~cm}-1$ was shifted to $2379.2 \mathrm{~cm}^{-1}$ by seventeen units, which may indicate the presence of intra-molecular $\mathrm{H}-$ $\mathrm{OH}$ frequency and $\mathrm{C} \equiv \mathrm{C}$.
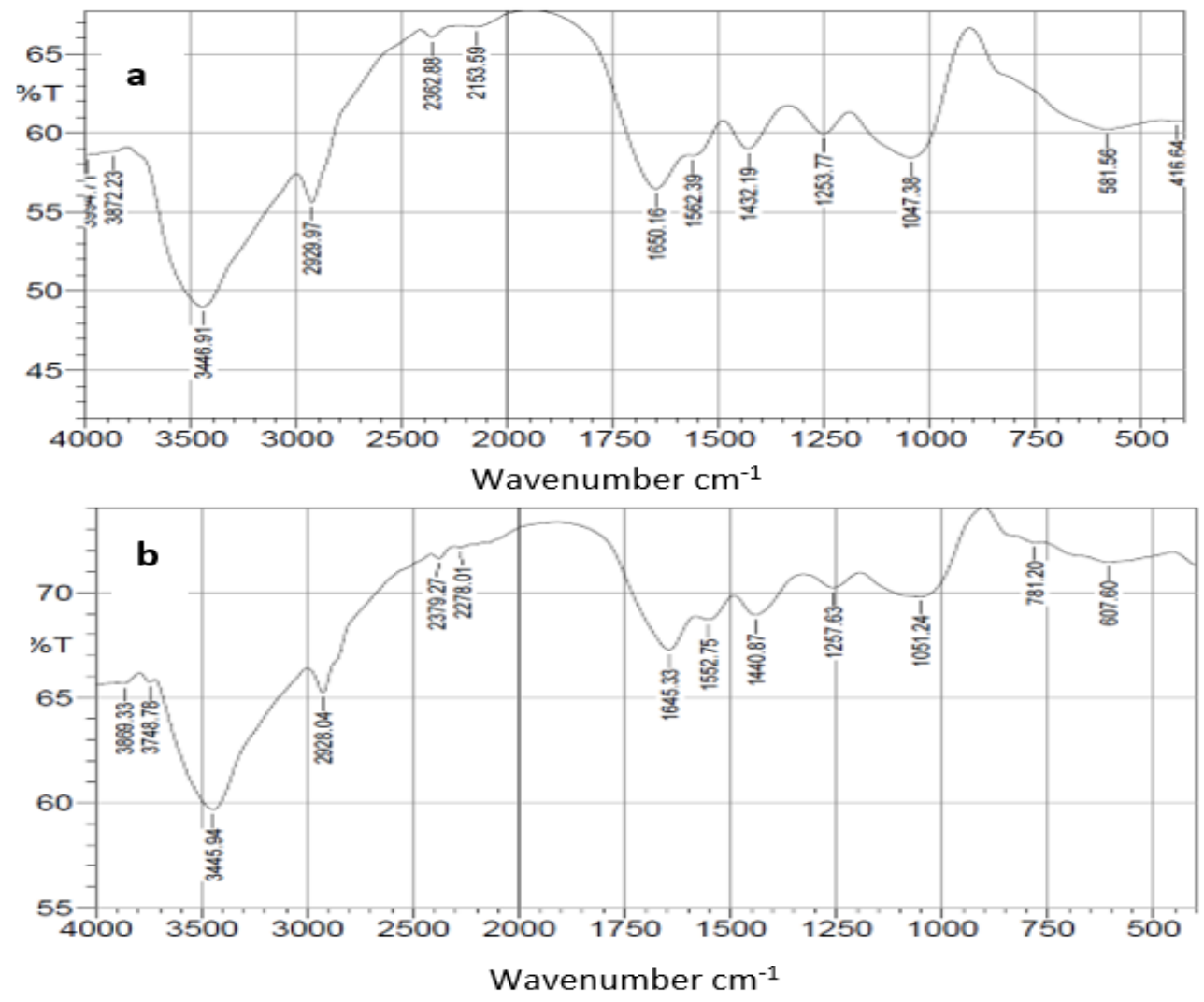

Fig.3: The FT-IR absorption spectrum of Ulva L. powder before (a) and after (b) adsorption of metal ions $\left(\mathrm{Ni}^{2+}\right.$ and $\left.\mathrm{Cd}^{2+}\right)$

The infrared spectra at $1650.1 \mathrm{~cm}-1$ were shifted to $1645.3 \mathrm{~cm}-1$ by five units accordingly of the adsorption route, and the bands indicate the aromatic structural vibrations $\mathrm{C}=\mathrm{C}, \mathrm{C}=\mathrm{O}$ spanning the quinone and amide groups, and $\mathrm{C}=\mathrm{O}$ of the 
conjugated H-bonded Ketones. The absorption band at $1562.3 \mathrm{~cm}-1$ was shifted to 1552.7 cm- 1 by ten units, the band indicate $\mathrm{C}=\mathrm{N}$ stretching of amides (amide band). The band at $1432.1 \mathrm{~cm}-1$ was shifted to $1440.8 \mathrm{~cm}-1$ by eight units, it is assigned to $\mathrm{O}-\mathrm{H}$ deformation. The band at $1047.3 \mathrm{~cm}-1$ was shifted to $1061.2 \mathrm{~cm}-1$ by fourteen units, which may indicate the presence of $\mathrm{C}-\mathrm{O}$ stretching for polysaccharides or polysaccharide-like substances and/or $\mathrm{Si}-\mathrm{O}$ of silicate impurities (Senesi et al., 2003). The stretching frequency of metal-OH was found at the $781.2 \mathrm{~cm}-1$, the peak at 581.5 $\mathrm{cm}^{-1}$ before metal adsorption was shifted to the peak at $781.2 \mathrm{~cm}-1$ due to the presence of $\mathrm{O}-\mathrm{H}$ deformation.

\section{Experimental study of adsorption}

The study of adsorption process was carried out by changing different variables; these parameters include the $\mathrm{pH}$, contact time, and initial concentration of metal ions to reach the most appropriate conditions for removing cadmium and nickel ions from the aqueous solution.

\section{Influence of pH-value on adsorption capacity}

The $\mathrm{Ph}$ - value has an effect on the site dissociation (proton and deprotonation of functional groups on adsorbents). It also affects heavy metal solution chemistry, hydrolysis and heavy metal speciation (Veena et al., 2012; Jaiswal et al., 2013; Adebayo et al., 2020). Through altering the $\mathrm{pH}$ values of the initial mixture in the range from 3 to 7, the ability of Ulva Lactuca powder to adsorb $\mathrm{Cd}^{2+}$ and $\mathrm{Ni}^{2+}$ ions was studied. The greatest amount of metal binding was recorded at $\mathrm{pH}$ 6.0. The adsorbate's ionization degree (species formation) and surface property may be affected by the $\mathrm{pH}$ (AbdelGhani et al., 2015). The amount of $\mathrm{Cd}^{2+}$ and $\mathrm{Ni}^{2+}$ ions adsorbed on the adsorbate study increases when the $\mathrm{pH}$ value rises from 3.0 to 6.0, as shown in Fig. (S1). With low pH values, Ulva Lactuca powder was very selective for $\mathrm{H}+$ ions, resulting in this occurrence. $\mathrm{H}+$ ions compete with metal ions for exchange sites in Ulva Lactuca powder at lower $\mathrm{pH}$ levels, resulting in poor metal ion removal (Goher et al., 2015).

The significant decline in competition among protons and $\mathrm{Cd}^{2+}$ and $\mathrm{Ni}^{2+}$ cations for the identical functional groups, as well as the lower in surface charge positivity, which results in a lower electrostatic repulsion between the surface and metal ions before ionexchange, can be explained by the increase in metal ion removal as $\mathrm{pH}$ rises. Ulva Lactuca powder adsorption findings revealed an optimum $\mathrm{pH}$ value of around 6.0, which is also significant in the discharge of treated effluents (required for neutral water or water reuse). At $\mathrm{pH}$ 6.0, the highest removal percentages for $\mathrm{Cd}^{2+}$ and $\mathrm{Ni}^{2+}$ were 76.16 percent for $\mathrm{Cd}^{2+}$ and 79.07 percent for $\mathrm{Ni}^{2+}$. The decrease in adsorption at higher $\mathrm{pH}$ (above $\mathrm{pH}$ 6.0) is probably due to the formation of insoluble hydroxide $(\mathrm{OH})_{2}$ (Abdennebi et al., 2017). Metal ion binding to Ulva Lactuca powder is influenced by chemical characteristics, which are frequently governed by the $\mathrm{pH}$ of the solution. In general, lowering the $\mathrm{pH}$ of a solution raises the concentration of free ionic species. Several 
investigations have found that the biosorption of metal ions is inversely proportional to the $\mathrm{pH}$ of the metal solution (El-Sikaily et al., 2007; Nessim et al., 2011). The influence of initial $\mathrm{pH}$ on the elimination of meta ions $\left(\mathrm{Cd}^{2+}\right.$ and $\left.\mathrm{Ni}^{2+}\right)$ was investigated using dried sea algae (Ulva Lactuca) (Fig. S1). The maximum removal occurred at initial pH 6.0 for both cadmium and nickel ions. The present results revealed that the removal $\%$ of metal ions increased from $64 \%$ to $76 \%$ for cadmium and from $73 \%$ to $79 \%$ for nickel with increasing the $\mathrm{pH}$ from 3.0 to 6.0 . While, it decreased to $61 \%$ and $75.64 \%$ for cadmium and nickel ions, respectively, at $\mathrm{pH}$ value above 6.0 (Fig. S1). Under low acid circumstances, the adsorption capacity was reduced in the current study. The equilibrium adsorption capacity (qe) increased slightly as the $\mathrm{pH}$ increased from 3.0 to 6.0, with the greatest absorption capacity at $\mathrm{pH} 6.0$, followed by a decrease at $\mathrm{pH} 7$. It can be concluded that $\mathrm{pH} 6.0$ had the optimum adsorption behavior and removal efficiency for cadmium and nickel ions (Figs. S1, S2). Cadmium and nickel ions can precipitate as metal hydroxides at $\mathrm{pH}$ levels greater than 6.0 (Chen \& Yang, 2005). When the $\mathrm{pH}$ value decreases, the hydrogen ions $\mathrm{H}+$ increase, and the competition between metal ions and $\mathrm{H}+$ ions for adsorption occurs on the surface of the biosorbent material. Conversely, the high $\mathrm{pH}$ value leads to a significant increase in the adsorption of metal ions due to the increase in the negative charge of the - $\mathrm{OH}$ group on the surfaces of the active sites of biosorbent material (Malandrino et al., 2006). At $\mathrm{pH}$ values greater than 5, where metal ions are surrounded by anions, a decreased removal of metal ions is recorded with the presence of the sorbent material (Adhiambo et al., 2015). As a result, the optimum $\mathrm{pH}$ value for cadmium and nickel ions was $\mathrm{pH}$ 6.0.

\section{Impact of contact time on biosorption efficiency}

One of the most important elements affecting adsorption capacity is the investigation of the influence of contact time between metal ions in the solution and the adsorbent material (Baysal et al., 2009). Using dried Ulva Lactuca powder, the relationship between contact time variations on the biosorption process and metal ions removal percent (cadmium and nickel ions) from aqueous solution is illustrated in Fig. (S3), it was investigated at various time periods in the range of 5-90 min. The initial concentration of cadmium and nickel ions removal was 10 and $50 \mathrm{mgL}-1$, respectively; the volume of solution was $250 \mathrm{ml}$; the $\mathrm{pH}$ value $=6.0$; the adsorbent dosage was $0.2 \mathrm{~g}$ and room temperature was $25^{\circ} \mathrm{C}$. Under those conditions, the results showed a good ability to from aqueous solution at the first $5 \mathrm{~min}$. The uptake of cadmium and nickel ions rose significantly at the start of the biosorption, but after 40 minutes, the change became gradual. At 60 minutes of the biosorption process, the metal ions on the biosorbent reached an equilibrium condition, according to the findings. After this equilibrium period, the amount of adsorbed cadmium and nickel ions did not change significantly with time, and the removal decreased significantly and eventually reached a plateau after 60 minutes. 
Consequently, the clearance efficiency was high, and 90 minutes was chosen as the biosorption equilibrium period. The results showed that increasing the contact duration between the metal ions and the adsorbent boosted metal ion removal efficiency from 47 to 75 percent for cadmium, and from 38 to 73 percent for nickel ions. Metal ions have access to adsorption sites on the biosorbent at first. As a result of the rise in metal ion concentration between the solution and the biosorbent material, it was found that adsorption is rapid. This is induced by the intramolecular diffusion in the cell walls of biosorbent from the liquid to the biosorbent surface, and the decrease occurred slowly thereafter. Additionally, the forces of repulsion between the adsorbent materials led to a decrease in the adsorption process (Agarry et al., 2015; Latinwo et al., 2015). Generally, Fig. (S3) shows that the adsorption process of metal ions by means of biosorbent occurs in two steps. In the first step, adsorption occured rapidly within the first 5 minutes (39$47 \%$ ) of the total cadmium and nickel ions adsorption by biosorbent (Ulva Lactuca powder). Whereas, in the second step to reach equilibrium, the process extended to be within 90 minutes.

\section{Effect of initial concentration on biosorption efficiency}

The driving force between the adsorbent and the metal ions solution, which affects the adsorption process, is the initial concentration. To study this variable, the initial concentration range was changed from 5 to $20 \mathrm{mgL}^{-1}$ for cadmium and from $20-100 \mathrm{mgL}^{-}$ ${ }^{1}$ for nickel, while all other variables were constant. On the dried Ulva L. powder, a rapid rise in cadmium and nickel adsorption was observed due to the existence of sites available on the surface of the biosorption material. As shown in Fig. (S4), the obtained results revealed that the removal rates decreased. Therefore, no significant effect was recorded on the adsorption process with further increase in cadmium concentration from 10 to $20 \mathrm{mgL}^{-1}$ and in nickel concentration from 50 to $100 \mathrm{mgL}^{-1}$. It is worthy to mention that, any increase in concentration record no effect on the adsorption process until the sites on the surface of the adsorbent become saturated with ions and reach equilibrium. Previous research has demonstrated that high concentrations cause spots on the surface of the biosorbent material until occupied. The unavailability of the evaluated sites and, consequently, the places of residence of the sorbets are reduced (Teka \& Enyew, 2014). Thus, the higher concentration also increased the uptake of sorbate at the available sites. These adsorption sites can easily be occupied by adsorption materials, and the adsorption capacity has a positive effect on the concentration in this range. The adsorption capacity (qe) of cadmium and nickel increased with different biosorbent doses $(0.1,0.2,0.5,1.0 \mathrm{~g})$ (Fig. S5).

\section{Effect of adsorption dose}

The effect of adsorption dose regarding the process of adsorption of metal ions (cadmium and nickel) was investigated by changing the dosage of the adsorbent from the aqueous solution while the other variables maintain its stability to reach the optimum amount of the adsorbent using different concentrations of metal ions (Mekonnen et al., 
2015). The effect of the adsorbent dose was studied by $250 \mathrm{~mL}$ of three different metal ions concentrations $\left(5,10,20 \mathrm{mgL}^{-1}\right.$ for cadmium and $20,50,100 \mathrm{mgL}^{-1}$ for nickel) under different adsorbent doses $(0.1,0.2,0.5$ and $1.0 \mathrm{~g})$ (Fig. S4). Increasing the mass of adsorbent resulted in a corresponding increase in the percentage of metal ion removal as shown in Fig. (S4).

Remarkably, adsorption tends to balance when the mass of the adsorbent material reaches a certain value. The metal ion removal rate reached the saturated value at the mass of the adsorbent of $0.2 \mathrm{~g}$ corresponding to the initial metal concentration of 10 $\mathrm{mgL}^{-1}$ for cadmium and $50 \mathrm{mgL}^{-1}$ for nickel. This happened due to the fact that when high doses of adsorbents are used, the amount of accessible metal ions in the solution is insufficient for adsorption on the adsorbent's surface. It is evident from the study that the values of absorption capacity (qe) decrease with increasing the dose of bioadsorbent (Ulva Lactuca powder) used for both cadmium and nickel ions, while the percentage of removal increases to 76 and $82 \%$ for both cadmium and nickel ions, respectively (Fig. S6). The rate of metal ion removal increased as the number of absorption pores and adsorption sites increased. Higher adsorbent amounts cause particle aggregation, which reduces total surface area and lengthens diffusion paths, both of which lead to a reduction in the quantity adsorbed per unit mass (Shukla et al.,2002). Gborbami et al. (2012) postulated that, an increase in the absorbent material's surface area and the availability of free surface charges on the binding sites resulted in a higher removal percent. Moreover, Adebayo et al. (2020) reported that, a high adsorbent dose can impose a sieve effect on the other dense layer of cells, thus protecting the binding sites from metal ions. Notably, 0.2 grams of the adsorbent material (Ulva Lactuca powder) is the appropriate dose to remove $\mathrm{Cd}^{2+}$ and $\mathrm{Ni}^{2+}$ ions.

\section{Effect of temperature}

The effect of temperature is an important factor affecting the adsorption performance. Various sets of experiments were performed to study the effect of this variable on adsorption and different temperatures $(273,298,303,308,313 \mathrm{~K})$, with $\mathrm{pH}$ value of 6 , initial concentration of $10 \mathrm{mgL}-1$ for $\mathrm{Cd}^{2+}$ and $50 \mathrm{mgL}-1$ for $\mathrm{Ni}^{2+}$, contact time of $90 \mathrm{~min}$. Fig. (S7) shows the effect of temperature on the adsorption process of $\mathrm{Cd}^{2+}$ and $\mathrm{Ni}^{2+}$ ions by Ulva Lactuca powder. It was noticed that the adsorption of $\mathrm{Cd}^{2+}$ and $\mathrm{Ni}^{2+}$ ions increases with increasing the temperature. The present results showed that the removal efficiency increases with increasing the temperature as maximum adsorption $(69.72 \%$ for $\mathrm{Cd}^{2+}$ and $73.03 \%$ for $\mathrm{Ni}^{2+}$ ) was achieved at $313 \mathrm{~K}$. The increase in the removal efficiency with the increase in temperature is attributed to the fact that a higher temperature activates metal ions to enhance adsorption at the coordination sites of the adsorbent, and hence, the metal cation moves faster (Buasri et al., 2012). An increase in temperature leads to some fast slow steps, and an increase in the number of active sites are thus recorded on the surfaces of the adsorbent (Jarup et al., 1998). Furthermore, the increase in adsorption with the increase in temperature is due to an increase in the dissolution of 
the adsorbent with temperature, which leads to a decrease in the resistance to mass transfer of the adsorbent in the boundary layer. Moreover, with increasing temperature, the diffusion rate is higher across the outer and inner boundary layer due to the decrease in solution viscosity with increasing temperature (Adebayo et al., 2020).

\section{DISCUSSION}

The metal ion adsorption kinetics model is significant in the study of adsorption processes for it helps to predict the adsorption pathway by determining the chemical and physical behaviour of the examined bio-sorbent material. A lot of information can be obtained by predicting the frequency of adsorption from the design of batch absorption systems. To achieve this, the ideal conditions for solute absorption kinetics must be determined for use on a broad level. The equilibrium period for the uptake of cadmium and nickel ions by Ulva Lactuca powder was determined by kinetic tests. In general, three numerical simulations were also used to evaluate the experimental results acquired from the adsorption of metal ions on biosorbent, including pseudo-first- and second-order kinetic templates, in addition to an intraparticle diffusion template (Weber \& Morris model). In the present study, an amount of $0.2 \mathrm{gm}$ of biosorbent was added to $0.25 \mathrm{~L}$ of metal solution ( $10 \mathrm{mgL}^{-1}$ for cadmium ions and $50 \mathrm{mgL}^{-1}$ for nickel ions) at a $\mathrm{pH}$ value of 6.0 for both metals, followed by shacking at $250 \mathrm{rpm}$ at $25^{\circ} \mathrm{C}$.

\section{Pseudo first-order kinetics}

Kinetic Data are often processed using Lagergren first-order equation, which works on describing the rate of absorption based on its capacity. A predominant equation for studying kinetics of metal ions is the first order Lagergren equation (Wen et al., 2006). This model is reliant on the Ulva Lactuca powder's capability. It is assumed that liquid and solid adsorption took place on a single layer of the adsorption surface (adsorbate). The following is a general representation of a pseudo first-order formula (Lagergren, 1898):

$$
\frac{d q_{t}}{d t_{t}}=K_{1}\left(q_{e}-q_{t}\right)
$$

Where, $\mathrm{k}_{1}$ : rate constant of adsorption $\left(\mathrm{L} \mathrm{min}^{-1}\right)$; $\mathrm{q}_{\mathrm{e}}$ : the capacity of powder adsorption at equilibrium, and $\mathrm{q}_{\mathrm{t}}$ is the capacity of powder adsorption $\left(\mathrm{mgg}^{-1}\right)$ at period $\mathrm{t}$. The integrated form of Eq. 4 becomes: $\mathrm{t}=0$ to $\mathrm{t}=\mathrm{t}$ and $\mathrm{qt}=0$ to $\mathrm{qt}=\mathrm{qt}$ after integration and application of boundary constraints $\mathrm{t}=0$ to $\mathrm{t}=\mathrm{t}$ and $\mathrm{qt}=0$ to $\mathrm{qt}=\mathrm{qt}$ :

$$
\operatorname{Ln}\left(\mathrm{q}_{\mathrm{e}}-\mathrm{q}_{\mathrm{t}}\right)=\operatorname{Lnq}_{\mathrm{e}}-\mathrm{K}_{\mathrm{1}} * \mathrm{t}
$$

The $\log \left(q_{e}-q_{t}\right)$ values are corelated well with $t$, where $k_{1}$ is the slope and $L n q_{e}$ is the intercept.

The current study indicates that there is no linear correlation with the experimental results during the period range, recording the specific kinetic model, which is evident from the value of the correlation coefficient $\left(\mathrm{R}^{2}\right.$ values for cadmium and nickel ions are 0.318 and 0.919 , respectively) (Fig. 4). 


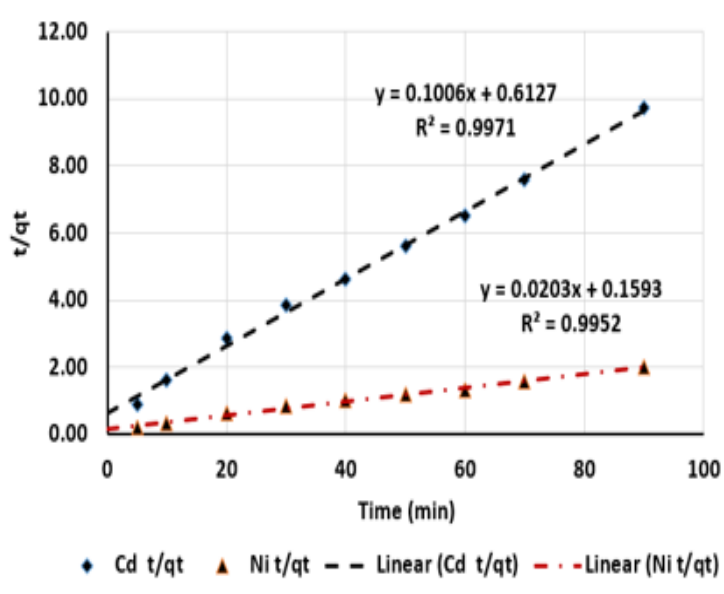

Pseudo second order (Ulva L.)

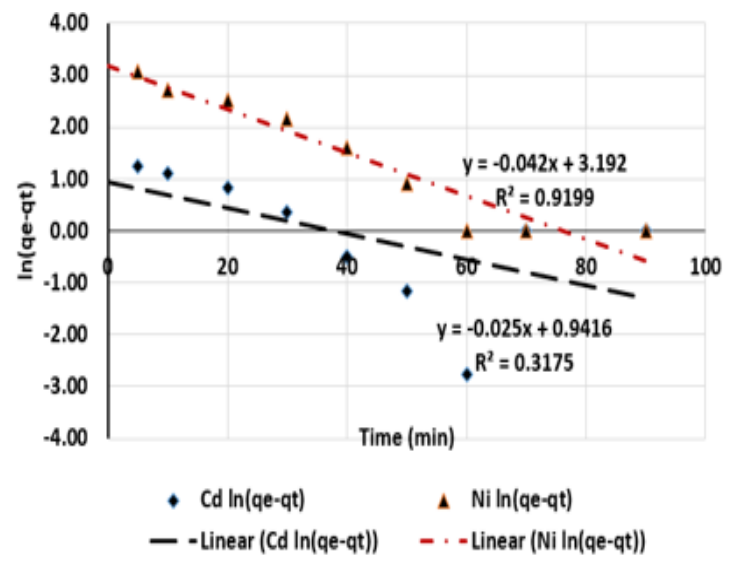

Pseudo first order (Ulva L.)

Fig. 4: Kinetic models for $\mathrm{Cd}^{2+}$ and $\mathrm{Ni}^{2+}$ adsorbed by Ulva Lactuca; pseudo-first order, and pseudosecond order kinetic for the adsorption of initial concentration of $\mathrm{Cd}^{2+}\left(10 \mathrm{mgL}^{-1}\right)$ and $\mathrm{Ni}^{2+}\left(50 \mathrm{mgL}^{-1}\right)$

The values of $k_{1}$ and qe (theoretical) for cadmium and nickel ions of biosorbent studied are shown in Table (1). The parameter for the first-order reveled qe (calculated) indicated that this model failed to estimate qe (experiment) since the experimental values of qe $\left(9.25 \mathrm{mg} \mathrm{L}^{-1}\right.$ and $45.0 \mathrm{mg} \mathrm{L}^{-1}$ for cadmium and nickel ions, respectively) differ from the calculated values of qe $\left(2.56 \mathrm{mg} \mathrm{L}^{-1}\right.$ and $24.34 \mathrm{mg} \mathrm{L}^{-1}$ for cadmium and nickel ions, respectively).

\section{Pseudo second-order kinetics}

This template explains well the adsorption kinetic based on the idea that the chemical adsorption is the controlling step during the reaction. The equation of this template can be expressed as follows (Ho et al., 1999):

$$
\frac{d q_{t}}{d_{t}}=K_{2}\left(q_{e}-q_{t}\right)^{\wedge}
$$

Where $k_{2}$ : the second-order rate adsorption constant $\left(\mathrm{g} \mathrm{mg}^{-1} \mathrm{~min}^{-1}\right)$. If $t=0$ to $t=t$ and $q_{t}=0$ to $q_{t}=q_{t}$, the combined form of Eq. 5 becomes:

$$
\frac{1}{\left(q_{e}-q_{t}\right)}=\frac{1}{q_{e}}+K_{2}
$$

Rearranging Eq. 5 yields Eq. 7, which has a linear form:

$$
\frac{t}{q_{t}}=\frac{1}{K_{2}} q_{e}^{2}+\left(\frac{1}{q_{e}}\right) * t
$$

Suppose $\mathrm{h}\left(\mathrm{g} \mathrm{mg}^{-1} \mathrm{~min}^{-1}\right)$ is the initial rate of adsorption:

$$
h=K_{2} q_{e}^{2}
$$


Therefore, Eqs. 7 and 8 are as described in the following:

$$
\frac{t}{q_{t}}=\frac{1}{h}+\frac{1}{q_{t}} *(t)
$$

The slope and intercept of the linear correlation graph were used to calculate $\mathrm{q}_{\mathrm{e}}$ and $\mathrm{k}_{2}$. Table (1) shows the computed adsorption kinetic constants and correlation coefficients for the two models utilized in this investigation. Good correlation coefficients $\left(\mathrm{R}^{2}\right)$ are reported for the metal ion removal process and can be approximated using the pseudo second order kinetics template, showing that the model can fit the experimental data. Furthermore, the theoretically estimated steady state biosorption ability, $\mathrm{q}_{\mathrm{e}}$ (theoretical), should be consistent with experimental biosorption capacity, $\mathrm{q}_{\mathrm{e}}$ (experimental) values.

Table (1) shows that, the correlation coefficients $\left(\mathrm{R}^{2}\right)$ were 0.997 for cadmium and 0.995 for nickel. The experimental qe was 9.25 and $45.0 \mathrm{mgL}^{-1}$ for $\mathrm{Cd}^{2+}$ and $\mathrm{Ni}^{2+}$, respectively. Those values revealed slight differences compared to the calculated ones (9.94and $49.26 \mathrm{mgL}^{-1}$ for cadmium and nickel ions, respectively) (Table 1). Obviously, from the values calculated by pseudo-second-order kinetic template, qe $_{\text {cal }}$ had good

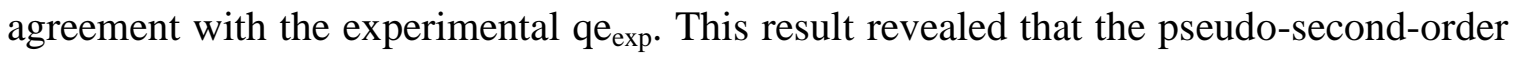
kinetic template was the best fit for explaining the cadmium and nickel ion adsorption process onto Ulva Lactuca powder as a biosorbent.

\section{The intraparticle diffusion adsorption model}

One of the most prevalent models in large-scale adsorption kinetics study is the intraparticle diffusion model (Tsibranska \& Hristova, 2011). The intraparticle diffusion template, also known as the Weber and Morris template, is used to assess kinetic data, with the intercept linked to mass transfer over the boundary layer and the exponent predicted to be 0.5 . The model was defined by Weber and Morris (1963) as follows:

$$
q_{t}=K_{d} \cdot t^{1 / 2}+C
$$

Where $\mathrm{C}$ is the intercept, and $\mathrm{kd}$ is the intra-particle diffusion rate constant. The slope of the linear interpolation was used to derive the rate constant $\mathrm{k}_{\mathrm{d}}$, and the values of $\mathrm{q}_{\mathrm{t}}$ correlated proportionally with the values of $t^{1 / 2}$ (Fig. 5). 
Table1: parameters of the adsorption mechanism of $\mathrm{Cd}^{2+}$ and $\mathrm{Ni}^{2+}$ onto dried Ulva Lactuca powder using three models

\begin{tabular}{|c|c|c|}
\hline Pseudo-first order & $\mathrm{Cd}$ & $\mathrm{Ni}$ \\
\hline Equation & $y=-0.025 x+0.9416$ & $y=-0.042 x+3.192$ \\
\hline Lnqe (Cal.) (mg/g) & 0.9416 & 3.192 \\
\hline qe (Cal.) & 2.5641 & 24.3371 \\
\hline qe (exp.) & 9.25 & 45.00 \\
\hline $\mathrm{k}_{1}(1 / \mathrm{min})$ & 0.025 & 0.042 \\
\hline $\mathrm{R}^{2}$ & 0.3175 & 0.9199 \\
\hline \multicolumn{3}{|l|}{ Pseudo-second order } \\
\hline Equation & $y=0.1006 x+0.6127$ & $y=0.0203 x+0.1593$ \\
\hline $\mathrm{Qe}(\mathrm{mg} / \mathrm{g})$ & 9.9403 & 49.2611 \\
\hline qe (exp.) & 9.25 & 45.00 \\
\hline $\mathrm{k}_{2}(\mathrm{~g} / \mathrm{mg}$ min $)$ & 0.01652 & 0.00259 \\
\hline $\mathrm{R}^{2}$ & 0.9971 & 0.9952 \\
\hline \multicolumn{3}{|c|}{ Weber and Morris model } \\
\hline Equation & $y=0.4876 x+4.0237$ & $\mathrm{y}=4.0534 \mathrm{x}+11.047$ \\
\hline \multicolumn{3}{|l|}{ qt } \\
\hline $\mathrm{k}_{\mathrm{d}}\left(\mathrm{mg} \mathrm{g}^{-1} \min ^{-1 / 2}\right)$ & 0.4876 & 4.0534 \\
\hline $\mathrm{C}$ & 4.0237 & 11.0470 \\
\hline $\mathrm{R}^{2}$ & 0.8340 & 0.8464 \\
\hline
\end{tabular}

For cadmium and nickel ions, the intercept (C) values were 4.024 and 11.047, respectively (Table 1). The external mass transfer resistance grows with rising the intercept increase values, giving an information about the thickness of the boundary layer. For biosorbent experiments, $\mathrm{R}^{2}$ values for cadmium and nickel ions were 0.834 and 0.846 , respectively, confirming that the intra-particle diffusion process is the controlling stage. The plots' linearity revealed that intra-particle diffusion was important in the uptake of cadmium and nickel ions by Ulva Lactuca powder as a bio-sorbent material. 


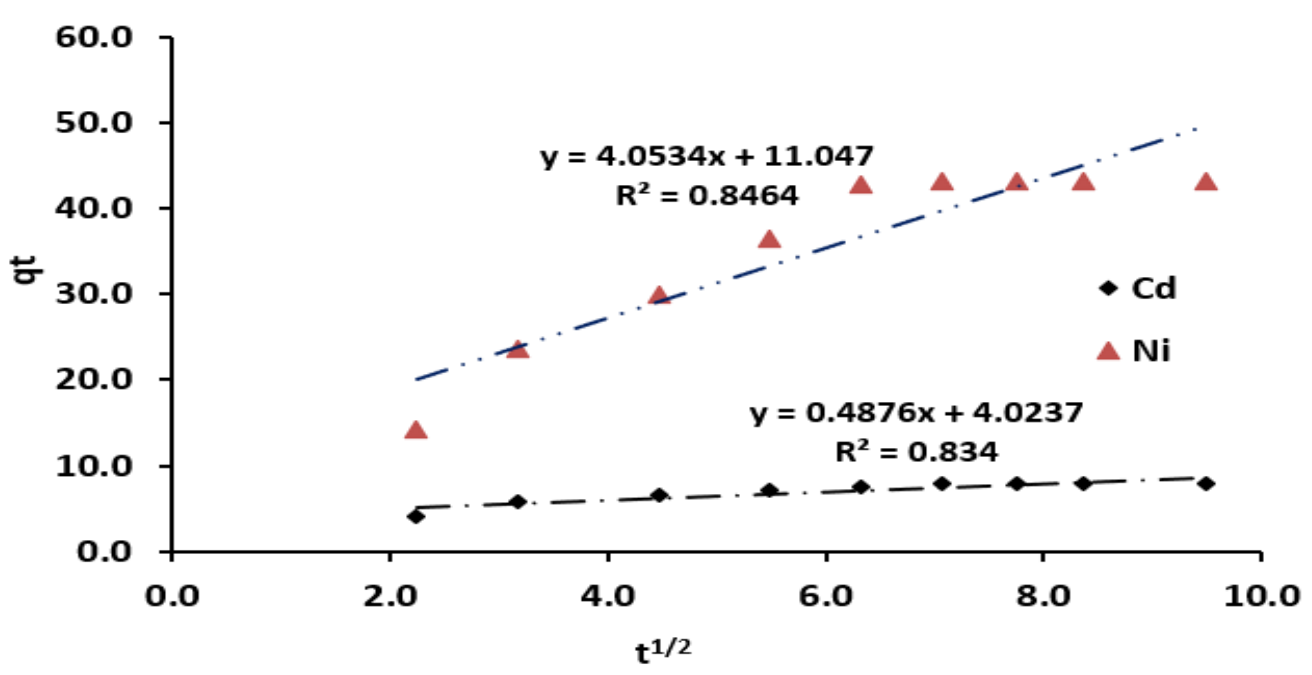

Fig. 5: The intraparticle diffusion model for the adsorption of initial concentration of $\mathrm{Cd}^{2+}$ (10mgL $\left.{ }^{-1}\right)$ and $\mathrm{Ni}^{2+}\left(50 \mathrm{mgL}^{-1}\right)$ by biosorbent (Ulva Lactuca powder)

The linear graphs of cadmium and nickel ions (Fig.5) did not, in fact, travel through the origin. The variation in the rate of mass transfer between the first and final stages of biosorption is responsible for this divergence from the origin. This suggests the presence of a boundary layer effect, as well as the fact that diffusion within the particles was not the only factor influencing the rate. The intra-particle model matched a straight line through the origin (Fig. 5), indicating that the adsorption process was influenced not only by intra-particle diffusion but also by other adsorption processes (Kuang et al., 2020).

\section{CONCLUSION}

The biosorbent Ulva Lactuca powder has a lot of promise for removing $\mathrm{Cd}^{+2}$ and $\mathrm{Ni}^{+2}$ ions from contaminated water. Within the first 60 minutes of interaction, the metals on the adsorbent were biosorbed to the point where 75 percent of the metals were eliminated. The biosorption that best fit the Pseudo-second order model was shown to be highly dependent on parameters, such as solution's $\mathrm{pH}$, contact time and biosorbent dose. The results suggest that Ulva Lactuca powder have potential application in $\mathrm{Cd}^{+2}$ and $\mathrm{Ni}^{+2}$ ions decontamination from aqueous effluents and that pretreatment further enhances biosorption. 


\section{REFERENCES}

Abdel-Ghani, N.T.; El-Chaghaby, G.A. and Zahran, E.M. (2015). Cost effective adsorption of aluminium and iron from synthetic and real wastewater by rice hull activated carbon (RHAC), American J. Analytical Chemistry.6:71-83. http://creativecommons.org/licenses/by/4.0/

Abdennebi, N.; Benhabib, K.; Goutaudier, C. and Bagane, M. (2017). Removal of aluminium and iron ions from phosphoric acid by precipitation of organometallic complex using organo phosphorous reagent. J. materials and Environmental Sciences, 8(2): 557-565.

Adebayo, G. B.; Adegoke, H. I. and Fauzeeyat, S. (2020). Adsorption of Cr (VI) ions onto goethite, activated carbon and their composite: kinetic and thermodynamic studies. Applied Water Science, 10:213 https://doi.org/10.1007/s13201-02001295-z

Adhiambo, O.R.; Lusweti, K. J. and Morang'a, G. Z. (2015). Biosorption of $\mathrm{Pb} 2+$ and $\mathrm{Cr} 2+$ Using Moringa Oleifera and their Adsorption Isotherms. Science Journal of Analytical Chemistry. Science Journal of Analytical Chemistry, 3(6):100-108. doi: 10.11648/j.sjac.20150306.14

Agarry, S. E.; Ogunleye, O. O. and Ajani, O. A. (2015). Biosorptive removal of cadmium (II) ions from aqueous solution by chemically modified onion skin: batch equilibrium, kinetic and thermodynamic studies. Chemical Engineering Communications, 202: 655-673. https://doi.org/10.1080/00986445.2013.863187

Ahmad, R.; Kumar, R. and Haseeb, S. (2012). Adsorption of $\mathrm{Cu} 2+$ from aqueous solution onto iron oxide coated eggshell powder:evaluation of equilibrium, isotherms, kinetics, and regenerationcapacity. Arabian Journal of Chemistry, 5(3):353-359. https://doi.org/10.1016/j.arabjc.2010.09.003.

Akar, T. and Tunali, S. (2006) . Biosorption characteristics of Aspergillus flavus biomass for removal of $\mathrm{Pb}$ (II) and $\mathrm{Cu}$ (II) ions from an aqueous solution. Bioresource Technology, 97(15):1780-1787. DOI: 10.1016/j.biortech.2005.09.009

APHA. (1998). Standard Methods for the Examination of Water and Wastewater. 20thEdn. American Public Health Association, Washington DC.

Baroni, P.; Vieira, R.S.; Meneghetti, E.; Beppu, M.M. and Silva, M.G.C. (2008). Evaluation of batch adsorption of chromium ions on natural and cross-linked chitosan membranes. Journal of Hazardous Materials, 152:1155-1163. DOI: 10.1016/j.jhazmat.2007.07.099

Baysal, Z.; Cinar, E.; Bulut, Y.; Alkan, H. and Dogu, M. (2009). Equilibrium and thermodynamic studies on biosorption of $\mathrm{Pb}(\mathrm{II})$ onto Candida albican biomass. $\mathbf{J}$ Hazard Mater, 161:62-67. DOI: 10.1016/j.jhazmat.2008.02.122 
Bhaumik, R. and Mondal, N.K. (2016). Optimizing adsorption offluoride from water by modified banana peel dust using responsesurface modelling approach. Applied Water Science,6(2): 115-135. https://doi.org/10.1007/s13201-014-0211-9.

Buasri A.; Chaiyut N.; Tapang K.; Jaroensin S. and Panphrom S. (2012). Equilibrium and Kinetic Studies of Biosorption of Zn (II) Ions from Wastewater Using Modified Corn Cob. APCBEE Procedia, 3: 60 - 64. doi: 10.1016/j.apcbee.2012.06.046

Chen, J.P. and Yang, L. (2005). Chemical modification of Sargassum sp. for prevention of organic leaching and enhancement of uptake during metal biosorption. Ind. Eng. Chem. Res., 44: 9931-9942

Davis, T.A.; Volesky, B. and Mucci, A.A. (2003). review of the biochemistry of heavy metal biosorption by brown algae. Water Research, 37:4311-4330. doi:10.1016/S0043-1354(03)00293-8

El-Said, G.F.; El-Sadaawy, M.M. and Aly-Eldeen, M.A. (2018). Adsorption isotherms and kinetic studies for the defluoridation from aqueous solution using eco-friendly raw marine green algae, Ulva lactuca. Environ Monit Assess, 190: 14. https://doi.org/10.1007/s10661-017-6392-6

El-Sikaily, A.; El Nemr, A.; Khaled, A. and Abdelwehab, O. (2007). Removal of toxic chromium from wastewater using green alga Ulva lactuca and its activated carbon. Journal of Hazardous Materials, 148:216-228. doi:10.1016/j.jhazmat.2007.01.146

Ertani, A.; Schiavon, M.; Altissimo, A.; Franceschi, C. and Nardi, S. (2011). Phenolcontaining organic substances stimulate phenylpropanoid metabolism in Zea mays L. J. Plant Nutr. Soil Sci., 3: 496-503. doi: 10.1002/jpln.201000075

Gborbami, M.; Eisazadeh, H. and Ghoreyishi, A. A. (2012). Removal of zinc ions from aqueous solution using polyaniline nanocomposite coated on rice hust. Iranica Journal of Energy \& Environment 3 (1): 66-71. DOI: 10.5829/idosi.ijee.2012.03.01.3343

Goher, M. E.; Hassan, A. M.; Abdel-Moniem, I. A.; Fahmy, A. H.; Abdo, M. H. and El-sayed, S. M. (2015). Removal of aluminum, iron and manganese ions from industrial wastes using granular activated carbon and Amberlite IR-120H, Egyptian J. Aquatic Research. 41 :155-164. https://doi.org/10.1016/j.ejar.2015.04.002

Guibal, E. (2004). Interactions of metal ions with chitosan-based sorbents: a review. Separation purification Technology. 38:43-74. doi:10.1016/j.seppur.2003.10.004

Ho, Y.S. and McKay, G. (1999). Pseudo-second order model for sorption processes. Process Biochemistry, 34(5): 451-465. https://doi.org/10.1016/S00329592(98)00112-5.

Ibrahim, W. M.; Hassan, A.F. and Azab, Y.A. (2016). Biosorption of toxic heavy metals from aqueous solution by Ulva lactuca activated carbon. Egyptian journal 
of basic and applied sciences, 3:241-249. http://dx.doi.org/10.1016/j.ejbas.2016.07.005

Jaiswal, A.; Banerjee, S.; Mani, R. and Chattopadhyaya, M.C. (2013). Synthesis, characterization, and application of goethite mineral as an adsorbent. J. Environ Chem Eng, 1:281-289. https://doi.org/10.1016/j.jece.2013.05.007

Jarup,L. et al. ,1998. Health effects of cadmium exposure - a review of the literature and a risk estimate, Scandinavian Journal of Work, Environment and Health, 24(3):1-51. https://www.jstor.org/stable/40966769

Kuang, Y. ; Zhang, X. and Zhou, Sh. (2020). Adsorption of Methylene Blue in Water onto Activated Carbon by Surfactant Modification. Water, 12(2):587. DOI: $10.3390 / w 12020587$

Lagergren, S. (1898). Zur theorie der sogenannten adsorption geloester stoffe, Veternskapsakad. Handl, 24:1-39

Latinwo, G. K.; Jimoda, L. A.; Agarry, S. E. and Adeniran, J. A. (2015). Biosorption of some heavy metals from Textile Wastewater by Green Seaweed Biomass. Universal Journal of Environmental Research and Technology, 5 (4): 210-219. www.environmentaljournal.org

Li, Z.; Li, L.; Hu, D.; Gao, C.; Xiong, J.; Jiang, H. and Li, W. (2019). Efficient removal of heavy metal ions and organic dyes with cucurbit [8] uril-functionalized chitosan. Journal of Colloid and Interface Science, 539:400-413. https://doi.org/10.1016/j.jcis.2018.12.078 0021-9797

Malandrino, M.; Abollino, O.; Giacomino, A.; Aceto, M. and Mentasti, E. (2006). Adsorption of heavy metals on vermiculite: influence of $\mathrm{pH}$ and organic ligands. Journal of Colloid and Interface Science, 299(2):537-546. https://doi.org/10.1016/j.jcis.2006.03.011

Mehta, S. K. and Gaur, J. P. (2005). Use of algae for removing heavy metal ions from wastewater: Progress and pros-pects. Critical Reviews in Biotechnology, 25: 113152. https://doi.org/10.1080/07388550500248571

Mekonnen, E.; Yitbarek, M. and Soreta, T.R. (2015). Kinetic and thermodynamic studies of the adsorption of $\mathrm{Cr}$ (VI) onto some selected local adsorbents South African, Journal of Chemistry, 68: 45-52. DOI: http://dx.doi.org/10.17159 /03794350/2015/v68a7

Mukhopadhyay, M. (2008). Role of surface properties during biosorption of copper by pretreated Aspergillus niger biomass. Colloids and Surfaces A: Physicochemical and Engineering Aspects, 329(1-2):95-99. DOI: 10.1016/j.colsurfa.2008.06.052

Nessim, R. B.; Bassiouny, A. R.; Zaki, H. R.; Moawad, M. N. and Kandeel, K. M. (2011). Biosorption of lead and cadmium using marine algae, Chemistry and Ecology, 27(6) : 579-594. http://dx.doi.org/10.1080/02757540.2011.607439 
Ofer, R.; Yerachmiel, A. and Shmuel, Y. ( 2003). Marine Macroalgae as Biosorbent for Cadmium and Nickel in Water. Water Environment Research, 75 (3):246-253. https://doi.org/10.2175/106143003X141033

Park, J.M.; Park, D. and Yun, Y. (2005). Use of dead fungal biomass for the detoxification of hexavalent chromium: screening and kinetics. Process Biochemistry, 40:2559-2565. doi:10.1016/j.procbio.2004.12.002

Pavasant, P. and Apiratikul, R. (2006). Sorption isotherm model for binary component sorption of copper, cadmium, and lead ions using dried green macroalga, Caulerpa lentillifera. Chemical Engineering Journal, 119:135-145. doi:10.1016/j.cej.2006.02.010

Romera, E.; González, F.; Ballester, A.; Blázquez, M.L.and Muñoz, J.A. (2008). Biosorption of heavy metals by Fucus spiralis. Bioresource Technology. 99:46844693. doi:10.1016/j.biortech.2007.09.081

Romera, E.; González, F.; Ballester, A.; Blázquez, M.L. and Muñoz, J.A. (2007). Comparative study of biosorption of heavy metals using different types of algae. Bioresource Technology. 98:3344-3353. doi:10.1016/j.biortech.2006.09.026

Sakellariadou, F. (2006). Spectroscopic studies of humic acids from subsurface sediment samples collected across the Aegean Sea. Mediterr Mar Sci, 7:11-17

Samarghandi, M.; Al-Musawi, T.; Mohseni-Bandpi, A. and Zarrabi, M. (2015). Adsorption of cephalexin from aqueous solution using natural zeolite and zeolite coated with manganese oxide nanoparticles. J of Mo Liq, 211:431-441. http://dx.doi.org/10.1016/j.molliq.2015.06.067

Sandau, E.; Sandau, P. and Pulz, O. (2004). Heavy metal sorption by microalgae, Acta Biotechnologica, 16:227-235.

Saravanan, A.; Brindha, V. and Krishnan, S. (2011). Studies on the structural changes of the biomass Sargassum sp. on metal adsorption. J. Adv. Bioinf, 2: 193-196.

Satpal, S. and Khambete, A. K. (2016). Wastewater Treatment Using Micro-Algae - A review Paper. International Journal of Engineering Technology, Management and Applied Sciences, 4(2) :188-192. www.ijetmas.com.

Senesi, N.; D'Orazio, V. and Ricca, G. (2003). Humic acids in the first generation of EUROSOILS. Geoderma, 116:325-344. https://doi.org/10.1016/S00167061(03)00107-1

Sheng, P.X.;Ting, Y.P.; Chen, J.P.; Hong, L.(2004). Sorption of lead, copper, cadmium, zinc and nickel by marine algal: Characterization of Biosorptive capacity and investigation of mechanisms, J. Colloid Interface Sci., 275: 131-141. doi:10.1016/j.jcis.2004.01.036

Sheoran, A. S. and Sheoran, V. (2006). Heavy metal removal mechanism of acid mine drainage in wetlands: a critical review. Minerals Engineering, 19:105-116. doi:10.1016/j.mineng.2005.08.006 
Shukla, A.; Zhang, Y.; Dubey, P.; Margrave, J.L. and Shukla, Sh. S. ( 2002). The Role of Sawdust in the Removal of Unwanted Materials from Water. Journal of Hazardous Materials, 95(1-2) :137-52. DOI: 10.1016/S0304-3894(02)00089-4

Teka, T. and Enyew, S. (2014). Study on effect of different parameters on adsorption efficiency of low cost activated orange peels for the removal of methylene blue dye. International Journal of Innovation and Scientific Research, 8:106-111. http://www.ijisr.issr-journals.org/

Tsibranska, I. and Hristova, E. (2011). Comparison of different kinetic models for adsorption of heavy metals onto activated carbon from apricot stones. Bulgarian Chemical Communications, 43(3) : 370 - 377.

Veena, Devi B.; Jahagirdar A.A. and Zulfqar Ahmed, M.N. (2012). Adsorption of chromium (VI) on activated carbon prepared from coconut shell. Int J Eng Res Appl., 2(5):364-370

Verma, R. and Dwivedi Pratima. (2013). Heavy metal water pollution- A case study. Recent Research in Science and Technology, 5(5): 98-99. http://recentscience.com/

Vieira, R.H.S.F. and Volesky, B. (2000). Biosorption: a solution to pollution? Internatl Microbiol, 3:17-24

Vieira, R.S. and Beppu, M.M. (2006). Interaction of natural and cross-linked chitosan membranes with $\mathrm{Hg}$ (II) ions. Colloids and Surfaces A: Physicochemical and Engineering Aspects, 279:196-207. doi:10.1016/j.colsurfa.2006.01.026

Wang, J. and Chen, C. (2009). Biosorbents for heavy metals removal and their future. Biotechnology Advances, 27:195-226. doi:10.1016/j.biotechadv.2008.11.002

Weber, W.J. and Morris, J.C. (1963). Kinetics of adsorption on carbon from solutions. J. of the Sanitary Engineering Division, 89(2): 31-60. https://doi.org/ 10. 1061/JSEDAI.0000430

Wen, D.; Ho, Y.S. and Tang, X. (2006). Comparative sorption kinetic studies of ammonium onto zeolite. J. Hazard Mater B133:252-256. doi:10.1016/ j.jhazmat.2005.10.020

Yaich, H.; Garna, H.; Besbes, S.; Paquot, M.; Blecker, C. and Attia, H. (2011). Chemical composition and functional properties of Ulva lactuca seaweed collected in Tunisia. Food Chemistry, 128 :895-901. doi:10.1016/j. foodchem. 2011.03.114

Yao, S.; Zhang, K.; Jiao, K. and Hu, W. (2011). Evolution of coal structures: FTIR analyses of experimental simulations and naturally matured coals in the Ordos Basin, China. Energy Explor Exploit., 29(1): 1-20. https://doi.org/10.1260/01445987.29.1.1 